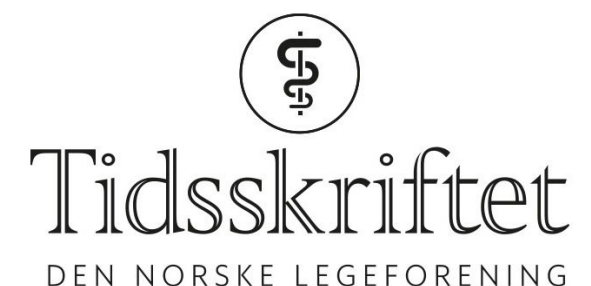

DEN NORSKE LEGEFORENING

\title{
God slagbehandling er mer enn akuttmedisin
}

DEBATT

\section{GURI HAGBERG}

E-post: guri.hagberg@gmail.com Guri Hagberg er overlege ved Seksjon for hjerneslag, Nevrologisk avdeling ved Ullevål sykehus og ph.d.-stipendiat ved Seksjon for geriatri, slag og rehabilitering ved Vestre Viken, Bærum sykehus. Forfatteren har fylt ut ICMJE-skjemaet og oppgir ingen interessekonflikter.

\section{ANNE CATHRINE BERG}

Anne Cathrine Berg er fysioterapeut og gruppeveileder ved Lærings- og mestringssenteret ved Vestre Viken, Bærum sykehus.

Forfatteren har fylt ut ICMJE-skjemaet og oppgir ingen interessekonflikter.

\section{TOMMY SKAR}

Tommy Skar er generalsekretær i LHL Hjerneslag. Forfatteren har fylt ut ICMJE-skjemaet og oppgir ingen interessekonflikter.

\section{MARIUS MYRSTAD}

Marius Myrstad er ph.d., spesialist i indremedisin og i geriatri, og overlege og postdoktor/forsker ved hhv. Seksjon for geriatri, slag og rehabilitering og Forskningsavdelingen ved Vestre Viken, Bærum sykehus.

Forfatteren har fylt ut ICMJE-skjemaet og oppgir ingen interessekonflikter.

\section{HÅKON IHLE-HANSEN}

Håkon Ihle-Hansen er ph.d. og konstituert overlege ved Seksjon for geriatri, slag og rehabilitering ved Vestre Viken, Bærum sykehus.

Forfatteren har fylt ut ICMJE-skjemaet og oppgir ingen interessekonflikter.

Pasienter som har gjennomgått hjerneslag, trenger et sikkerhetsnett etter utskrivelsen fra sykehuset.

Om lag 12 ooo pasienter rammes av hjerneslag i Norge hvert år (1). Tross fallende insidensrate og mer avansert akuttbehandling er hjerneslag den vanligste årsaken til uførhet og innleggelse på sykehjem, og den tredje vanligste dødsårsaken i Norge $(2,3)$. Trombolyse er som regel aktuelt ved ankomst til sykehuset innen 4,5 timer etter symptomdebut, trombektomi innen 24 timer $(4,5)$. Effekten er bedre desto raskere behandlingen gis. I dag behandles $20 \%$ av pasienter med hjerneinfarkt med trombolyse og $5 \%$ med trombektomi, en økning fra $1 \%$ i 2014 (1).

To av tre hjerneslag er definert som milde, og $44 \%$ av pasientene utskrives til egen bolig. Tre måneder etter slaget er likevel bare halvparten av pasientene like fornøyd med tilværelsen 
som før hjerneslaget, yrkesdeltakelsen er halvert, 17 \% får ikke dekket sitt hjelpebehov, og $24 \%$ har fått mindre trening enn de ønsker (1). Mange pasienter har «skjulte utfall» som fatigue og konsentrasjonsvansker.

I løpet av den akutte sykehusinnleggelsen skal etiologien om mulig avklares og riktig sekundærprofylakse igangsettes. Tverrfaglig kartlegging skal avdekke følger av slaget, tidlig rehabilitering skal igangsettes, og videre oppfølging skal planlegges. Pasient og pårørende skal informeres om sykdommen og behandlingen, noe som kan være utfordrende i løpet av et kort sykehusopphold og rett etter en akutt hendelse. Tidligere studier har vist at pasienter og pårørende ofte har lite kunnskap om sykdommen og dens konsekvenser $(6,7)$. Ved Bærum sykehus er den gjennomsnittlige liggetiden for de cirka zoo hjerneslagpasientene som behandles årlig, fem døgn (1). Mange pasienter og pårørende har fortalt at de har følt seg alene og hatt mange ubesvarte spørsmål etter utskrivelse fra sykehuset.

Slagdagen er et møtepunkt for pasient, pårørende, brukerorganisasjonene, kommunene og primær- og spesialisthelsetjenesten

Selv om de fleste av våre slagpasienter tilbys poliklinisk oppfølging etter tre måneder, har vi sett at det er behov for mer omfattende og systematisk opplæring og oppfølging av pasienter med hjerneslag (8).Vi foreslår en modell som tar høyde for en heterogen pasientgruppe med ulike behov. Modellen innebærer et samarbeid mellom alle de ulike aktørene som er involvert i pasientforløpet, der sykehuset blir et naturlig utgangspunkt.

\section{Slagdag}

Slagdag ble etablert ved Bærum sykehus som et tilbud til pasienter med hjerneslag og deres pårørende i 2017. Slagdagen er et møtepunkt for pasient, pårørende,

brukerorganisasjonene, kommunene og primær- og spesialisthelsetjenesten. Hovedmålet er å bedre pasientenes situasjon gjennom økt mestring av den nye livssituasjonen.

Slagdag avholdes seks ganger årlig på Lærings- og mestringssenteret med grupper på opptil 30 deltakere. Pasienter henvises både til Slagdag og poliklinisk tremånederskontroll uavhengig om de skrives ut tilbake til hjemmet eller til en opptreningsinstitusjon (figur 1).

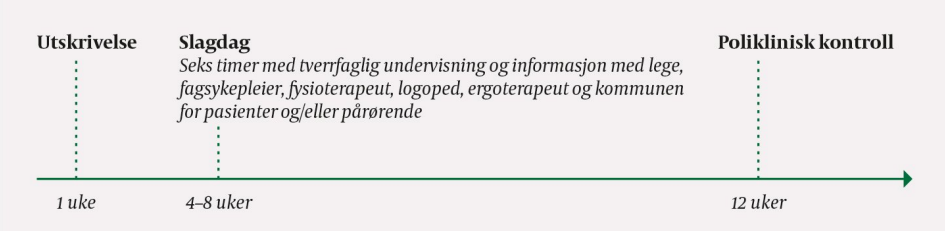

Figur 1 Pasientforløp etter utskrivelse ved Bcerum sykehus. Pasienter henvises både til Slagdag og poliklinisk kontroll uavhengig om de skrives ut til hjemmet, til rehabilitering hjemme eller til en opptreningsinstitusjon.

Slagdagen går over seks klokketimer, og pasienten må betale en egenandel som ved en vanlig sykehuskontakt. Noen ganger deltar kun pårørende. Samtlige yrkesgrupper som er involvert i pasientforløpet, bidrar med innlegg og undervisning - både tverrfaglig team på sykehuset, representant for fastlege, brukerorganisasjonene og kommunene. Deltakere får med seg skriftlig informasjonsmateriell hjem med viktige kontaktpersoner og telefonnummer.

\section{Evaluering}

Tilbakemeldinger fra pasienter og pårørende har så langt vært positive. Vi mener kommunikasjonen mellom primær- og spesialisthelsetjenesten har bedret seg med dette møtepunktet, og at man har fått en bedre forståelse av egne og andres ansvarsområder, i tråd med samhandlingsreformen (9). Det oppleves nyttig at det til enhver tid er personer i kommunene som har kjennskap til tilbud for pasientene, og at denne informasjonen 
oppdateres kontinuerlig.

Moderne hjerneslagbehandling er mer enn god akuttmedisin. Vi tror vår modell, med lokale tilpasninger, vil kunne brukes flere steder til beste for mange pasienter etter hjerneslag, og deler gjerne våre erfaringer med andre.

\section{LITTERATUR:}

1. Fjærtoft H, Indredavik B, Mørch B et al. Norsk Hjerneslagregister. Årsrapport 2018. Trondheim, St. Olav hospital, 2019. https://stolav.no/Documents/Årsrapport\%20NHR.pdf Lest 16.10.2019.

2. Bruun T, Denison E, Gjersing L et al. Folkehelserapporten - kortversjon: Helsetilstanden i Norge 2018. 2. utg. Oslo: Folkehelseinstituttet, 2018.

https://www.fhi.no/globalassets/dokumenterfiler/rapporter/2018/helsetilstanden-i-norge-20182.pdf Lest 16.10.2019.

3. Ellekjaer H, Selmer R. Hjerneslag-like mange rammes, men prognosen er bedre. Tidsskr Nor Lægeforen 2007; 127: 740-3. [PubMed]

4. Nogueira RG, Jadhav AP, Haussen DC et al. Thrombectomy 6 to 24 hours after stroke with a mismatch between deficit and infarct. N Engl J Med 2018; 378: 11-21. [PubMed][CrossRef]

5. Albers GW, Marks MP, Kemp $S$ et al. Thrombectomy for stroke at 6 to 16 hours with selection by perfusion imaging. N Engl J Med 2018; 378: 708-18. [PubMed][CrossRef]

6. Rønning OM, Thommassen L, Russell D. Kvalitetsindikatorer for behandling av akutt hjerneslag. Tidsskr Nor Lægeforen 2007; 127: 1219-23. [PubMed]

7. Faiz KW, Labberton AS, Thommessen B et al. Stroke-related knowledge and lifestyle behavior among stroke survivors. J Stroke Cerebrovasc Dis 2019; 28: 104359. [PubMed][CrossRef]

8. Hagberg G, Ihle-Hansen H, Ihle-Hansen H. Optimal slagbehandling - et felles ansvar. Indremedisineren 2016; 7:22-5.

9. Helse- og omsorgsdepartementet. St.meld. nr. 47 (2008-2009). Samhandlingsreformen. Rett behandling - på rett sted - til rett tid.

https://www.regjeringen.no/no/dokumenter/stmeld-nr-47-2008-2009-/id567201/sec1 Lest 16.10.2019.

Publisert: 13. november 2019. Tidsskr Nor Legeforen. DOI: 10.4045/tidsskr.19.0574

Mottatt 10.9.2019, første revisjon innsendt 11.10.2019, godkjent 16.10.2019.

(C) Tidsskrift for Den norske legeforening 2020. Lastet ned fra tidsskriftet.no 